\title{
Development of Financial Literacy and Anti- Corruption Education in Primary Schools Through Storytelling Activities
}

\author{
Maya Kuswati \\ Universitas pendidikan indonesia \\ Mayakuswaty22@gmail.com
}

\begin{abstract}
Financial literacy and anti-corruption education are two interrelated entities. The deeper meaning when someone already has the ability to understand financially, must be accompanied by the knowledge of bad practices from financial crime. Call it a form of corruption crime that is currently rampant. Strangely this is sometimes done by those who already understand and understand financial material. Unfortunately, it has only not been able to fortify itself from the tricks of deception money and its mortal pleasures. If left unchecked it will certainly be a dark tale of all time for the next generation of the nation. Therefore, it is very important to turn the tale into a good tale of travel in fortifying itself from bad practices such as corruption crimes and the like. The research method in this study was to study descriptively the development of financial literacy and anti-corruption education in elementary schools through storytelling activities. Primary school is a strategic educational unit to instill anti-corruption values. This is supported by the characteristics of students in concrete operational categories and the golden age of establishing a strong identity through fun activities such as storytelling activities. Storytelling activities are considered effective in instilling anti-corruption values with light language for children without reducing the essence of the expected value.
\end{abstract}

Keywords: financial literacy, anti-corruption education, and storytelling activities.

\section{Introduction}

Tepping on 19 years from the comfort of the 20th century, now the world is changing, dynamic, and without limits. People are loved by many life skills that must be prepared to survive in an era full of challenges. All efforts are taken to trigger 21 st century skills that must be possessed by students to prepare themselves in the life to come. The Conference Board of Canada (2000) has identified work skills in three areas: Fundamental Skills (Communicating, Managing Information, Using Numbers, Thinking, and Solving Problems); Personal Management Skills (Demonstrating Positive Attitudes and Behavior, Responsibility, Adapting, Continuous Learning, Working Safely); and Teamwork Skills (Working with Others, Participating in Projects and Tasks). It has also profiled innovation skills in the following areas: - creativity skills, problem solving, and continuous improvement; - risk assessment skills and risk taking; relationship building skills and communication; - implementation skills (Ontario, 2016, p. 10). 
These skills are developed directly in the formal education process in schools. Partnership for 21st Century Skills (2008, p. 13) describes the main subjects developed including: Art of English, reading or language; world language; Art; Mathematics; economy; science; Geography; History; government and citizenship. While the theme in the 21 st Century that was echoed in the process of developing life skills included: Global awareness; Financial, economic, business and entrepreneurial literacy; Citizenship literacy; Health literacy. This theme is very crucial and important to learn from basic education.

The focus on financial literacy is crucial and has an important role in the economy. Even knowing the meaning of money as a medium of exchange is not enough. Must be equipped with knowledge about how to manage finance so that it can be applied wisely and avoid consumptive patterns. In addition, good knowledge of finance will increase awareness of deviant behavior which must be avoided. Common deviant behaviors such as corruption. So from that knowledge about financial literacy must be juxtaposed with the planting of anti-corruption values so that acts of abuse are spared from every individual in the community.

\subsection{Financial Literacy}

Literacy is generally seen as a reading activity. The term literacy has a growing meaning. Early development period, literacy was defined as the ability to use language and images in a rich and varied form to read, write, listen, speak, see, present, and think critically about ideas (Abidin, Mulyati, and Yunansah, 2017, p. 1). The development of the two concepts of literacy is characterized by a number of views as social and cultural practices rather viewed as context-free cognitive achievements (Abidin, Mulyati, and Yunansah, 2017, p. 2). Furthermore, the third generation of literacy was expanded by the rapidly expanding information and multimedia technology (Abidin, et al., 2017, p. 2). Developing in the fourth generation according to Freire (Abidin, Mulyati, and Yunansah, 2017, p. 2) literacy is seen as a social construction and is never neutral. Continuing to experience development until the fifth genration, the term literacy becomes complex into multiliteration (Abidin, Mulyati, and Yunansah, 2017, p. 3).

Baguley, Pullen, and Short in Abidin (2015, p. 56) view multiliteration as a way to better understand the literacy curriculum learned in formal schools that encourages students to be able to participate productively in the community. Facing the development of the 21 st century, of course multiliteration skills are needed by students to be ready to face the situation related to increasingly fierce global competition. Century 21 multiliteration competencies include: basic literacy, health literacy, verbal / numerical literacy, information literacy, media literacy, visual literacy, scientific literacy, road safety literacy, cultural literacy. Financial literacy is part of the basic literacy component that students must have as a daily life skill.

Financial service authority regulation (OJK) No. 26 of 2016 concerning Financial Literacy and Inclusion Improvement in the Financial Services Sector for Consumers and / or Communities Chapter I Article 1 Paragraph 6 defines financial literacy as knowledge, skills, and beliefs that influence attitudes and behaviors for improve the 
quality of financial decision making and management in order to achieve prosperity. Furthermore, the Ministry of Education and Culture GLN Team (2017, p. 5) defines financial literacy as knowledge and skills to apply understanding of concepts and risks, skills to make effective decisions in the financial context to improve financial wellbeing, both individually and socially, and can participate in the community. The difference in terms of financial or financial literacy does not change the meaning that financial literacy is knowledge about finance, financial management skills, and one's ability to position themselves in making decisions regarding financial sundries.

\subsection{Basic Principles of Financial Literacy}

The basic principles of financial literacy according to the Ministry of Education and Culture GLN Team (2017, pp. 5-6) include:

1. Integrity (holistic) elements of financial literacy synergize with five other basic literations, with 21 st century skills.

2. Integration (integrated) with competence, character quality with five other basic literations. Integration with various domains, both schools, families and communities.

3. Responsive to local wisdom and religious teachings in Indonesia. Contains content that considers local wisdom and religious teachings that are very diverse in Indonesia.

4. Responsive health: considering, responsive, and utilizing things related to financial literacy that come from anywhere (universal).

5. Inclusive: embrace all parties openly and equally; open opportunities or opportunities and possibilities that come from other parties.

6. Participatory: involves, utilizes, utilizes various financial literacy stakeholders, and various resources owned by various stakeholders.

7. Conformity of psychological, social and cultural developments: materials, programs, and financial literacy activities are in harmony with individual development, social development, and the surrounding culture or shade of individuals.

8. Sustainability: all programs, activities, and results must continue and support each other.

9. The reliability of all programs, activities and financial literacy results must be accountable to all stakeholders of literacy and can be accessed and reviewed by other parties.

\subsection{Scope of Financial Literacy}

The scope of financial literacy material needs to be studied according to the Ministry of Education and Culture GLN Team (2017: 6-7) as follows:

1) Definition of economic transactions and various types of practices: Definition of exchange instruments, goods and services

2) Introduction of economic resources (income):

- Natural resources (SDA). Potential to recognize and use natural resources for shared prosperity and prosperity; 
- Human resources (HR). HR for livelihood / profession to fulfill basic needs.

3) Introduction to the concept of shopping (spending) as meeting basic needs:

- Prioritas Priority scale, namely primary, secondary and tertiary needs;

- Simple socialization and lifestyle campaigns;

- Consumer science.

4) The introduction of saving concepts in traditional and modern terminology: Savings, Insurance, Investment

5) Introduction of the concept of sharing based on local wisdom, religious teachings, and the state: charity and tax

6) Introduction to concepts about bad practice and crime financial: corruption, unofficial investment, other types of financial crime

The six scope of financial literacy material can be taught at the level of basic education with a portion adjusted to basic competencies in thematic subjects (social science, citizenship education, religious education).

\subsection{Anti-corruption Education}

Anti-corruption education according to Wijaya (2014, p. 24) anti-corruption education is a conscious effort to provide understanding and prevention of acts of corruption committed through formal education in schools, informal education in the family environment, and non-normal education in the community. Nurdin (2014, p. 30) explains that anti-corruption education is more than the cognitive dimension, but must also be included in the affective dimension. The point is that anti-corruption education needs to be done by providing cognitive understanding and affective proof in everyday life.

\subsection{Objectives and targets of anti-corruption education}

Handoyo (2013, p. 43) explains the objectives of anti-corruption education including: (1) as the formation of knowledge and understanding of various forms of corruption and its aspects; (2) changes in perceptions and attitudes towards corruption; and (3) the formation of new skills and skills needed to fight corruption. The opinion of Handoyo emphasizes the purpose of anti-corruption education, namely to provide awareness of hazards and strategies that can divert from the effects of corruption, by developing skills that are more dynamic according to changing needs. Deeper, Wijaya (2014, p. 25) formulates the objectives of anti-corruption education including:

1) Building school life as part of the community through the creation of a culture of culture with integrity (anti-corruption). Culture created in the form of an environment that is honest, disciplined, fair, responsible, hard working, simple, independent, brave, caring, and dignified.

2) Developing the potential of the heart / conscience of students through the affective realm as a person who has a sensitivity and always upholds cultural values as a way of loving the homeland and supported by strong national insight. 
3) Growing attitudes, behaviors, habits that are commendable in line with universal values and religious cultural traditions.

4) Instill a professional and responsible leadership spirit as the nation's next generation.

5) Organizing school management in an open, transparent, professional, and responsible manner.

\subsection{Storytelling Activities}

In general, storytelling can be defined as the art of storytelling or communication that uses elements of language, vocals, and gestures that are used to the maximum extent possible to communicate directly and turn on the story to the audience or audience (Ka WeEs, 2016, p. 4). every story or tale that is made certainly has the intended meaning and purpose. Tales that are told orally by the teacher at the school will give a special impression on students. Of course students will feel like they are involved in a fairy tale, and a good psychological connection exists between the teacher and students. The big difference in storytelling activities is that storytellers will convey a new spirit that is strong and shows a vivid picture in front of the listener. Providing clear and interesting portraits, intonations, movements, and emotions can turn every character with character as required in the story (Majid, 2017, p.28). The following are steps in carrying out financial literacy learning and anti-corruption characters through modified tales from various sources (Majid, 2017; Ka WeEs, 2016; Agus, 2008) and divided into three stages:

1) Preparation of storytelling: Understanding listeners or students; choose the story to be read; and preparation before entering class.

2) Storytelling process: Pay attention to the student's sitting position.

3) Follow up after storytelling

\section{Research methods}

The research approach used is descriptive research. Sukmadinata (2010, p. 7.3) explains that descriptive research is a study that describes conditions as they are without manipulation or giving treatment to independent variables. Descriptive research aims to describe facts and objects that are systematically and precisely examined (Sukardi, 2013, p. 157). In other words, descriptive studies explain something to what is in the field. The results of the descriptive study, only in the form of descriptive research results without treatment.

\section{Discussion}

In the first financial literacy material on economic transactions and various types of practices, it is described regarding the use of money as a medium of exchange. The existence of money as a medium of exchange is certainly very close to the lives of children. Parents will indirectly show the function of money when exchanging with groceries. The process is certainly very sticky, especially when a mother takes her child 
to shop. Thus, parents should provide an easy-to-understand explanation of the role of money in daily life.

Rapih (2016) explains that a basic understanding of financial literacy education in children will make children grow up with the provision of sufficient financial literacy and have a strong foundation for understanding financial issues and problems around them. Going deeper into financial literacy material, parents and teachers are more in preparing for the introduction of concepts about bad practice and financial crime. Specifically, bad practices that are commonly carried out such as corruption crimes. Preventing this from happening, basic values need to be strengthened to avoid the desire for corruption and other forms of financial crime. Wahyuny (2015) explained based on the results of his study that it is necessary to integrate anti-corruption values in Financial Literacy education to improve the quality of Indonesian people to have financial management capabilities that are also of anti-corruption value so that future Indonesian people can manage their finances well and without corruption.

Nuryanto (2016) explains that fairy tales are part of the method of education for early childhood. Anti-corruption education can be included in fairytale content by adding anti-corruption values. Anti-corruption values that can be included include values of responsibility, discipline, honesty, simplicity, independence, hard work, fairness, courage, and care. Furthermore, these values are conveyed by playing roles so students can feel them. And apply it in daily life through exemplary and habituation.

At present to realize anti-corruption education in schools must be oriented to the moral action level (Asmorojati, 2017). This orientation was developed to improve individuals before changing a more complex order. Thus financial literacy learning activities and the planting of anti-corruption values can be started by influencing individuals verbally, namely through storytelling activities. Noor (2011, p. 50) explained that storytelling activities have benefits such as honing the power of thought and imagination, as an effective media in instilling values and ethics in children, and as a first step to foster interest in reading children. These benefits can be maximized by parents and teachers in a more enjoyable learning process.

In today's digital era, parents and teachers can access financial literacy and anticorruption material that can be done at home or school. The financial services authority team (OJK), the corruption eradication commission (KPK) has collaborated with educational institutions in developing fun learning resources to introduce financial literacy and anti-corruption education through fairy tales. The contents of the fairy tales are presented complete with the values needed by children to be aware and able to fortify themselves from the latent danger of corruption.

An example of a series 1 anti-corruption fable book launched by the KPK team is "a story from a sincere grandfather." In the book explained about how to tell stories for children. There are 9 stories that instill 9 anti-corruption values. Orangtuan and the teacher can choose a fairy tale according to their psychological needs and conditions when they are going to do storytelling activities. 


\section{Conclusion}

Learning about anti-corruption financial and education literacy must be integrated into formal, informal and non-formal learning. The forms of financial literacy learning and anti-corruption value planting in formal and informal environments can be done in the form of storytelling activities. Storytelling has benefits that can influence the mindset and empathy of children in interpreting the values given.

\section{References}

[1] Abidin, Yunus. 2015. Pembelajaran Multiliterasi. Bandung: PT Refika Aditama

[2] Abidin, Mulyati, dan Yunansah. 2017. Pembelajaran Literasi: Strategi Meningkatkan

[3] Kemampuan Literasi Matematika, Sains, Membaca, Dan Menulis. Jakarta: Bumi Aksara

[4] Agus DS. (2008). Mendongeng Bareng Kak Agus DS Yuk.... Yogyakarta: Kanisius

[5] Asmorojati, Anom Wahyu. (2017). Urgensi Pendidikan Anti Korupsi dan KPK dalam

[6] Pemberantasan Tindak Pidana Korupsi di Indonesia. Prosiding The 6th University Research Colloquium, Universitas Muhammadiyah Magelang

[7] Handoyo, Eko. (2013). Pendidikan Antikorupsi. Yogyakarta: Penerbit Ombak

[8] Kak WeES. (2016). Mari Mendongeng. Yogyakarta: Zora Book

[9] Majid, A.A.A. (2017). Mendidik Dengan Cerita. (Neneng Yanti Kh. Dan Iip Dzulkifli Yahya) Bandung: PT Remaja Rosdakarya

[10] Nuryanto, Sidik. (2016). Dongeng Sebagai Pendidikan Anti Korupsi Pada Anak Usia Dini.

[11] INDRIA: Jurnal Ilmiah Pendidikan PraSekolah dan Sekolah Awal. Pp. 54-68 http://journal.umpo.ac.id/index.php/indria/index

[12] Noor, R.M. (2011). Pendidikan Karakter Berbasis Sastra: Solusi Pendidikan Moral Yang Efektif. Yogyakarta: Ar-Ruzz Media

[13] Nurdin, Muhamad. (2014). Pendidikan Antikorupsi. Yogyakarta: Ar-Ruzz Media

[14] Ontario. (2016). 21ST CENTURY COMPETENCIES. Queen's Printer for Ontario

[15] Partnership for 21st Century Skills. (2008). 21st Century Skills, Education \& Competitiveness; A RESouRCE And PoliCy GuidE. www.21stcenturyskills.org

[16] Rapih, Subroto. (2016). Pendidikan Literasi Keuangan Pada Anak: Mengapa dan Bagaimana?. Scholaria, 6 (2). Pp. 14-28

[17] Salinan Peraturan otoritas jasa keuangan (OJK) No 26 Tahun 2016 tentang Peningkatan 
[18] Literasi Dan Inklusi Keuangan Di Sektor Jasa Keuangan Bagi Konsumen dan/atau Masyarakat Bab I Pasal 1 Ayat 6

[19] Sukardi, Dewa Ketut. (2013). Pengantar pelaksanaan program bimbingan dan konseling di sekolah. Jakarta: PT Rineka Cipta

[20] Sukmadinata, Nana Syaodih. (2010). Metode penelitian Pendidikan. Bandung: PT Remaja Rosdakarya

[21] Tim studi dan kementrian pariwisata ekonomi kreatif. (2015). Jakarta: Republik Solusi

[22] Tim GLN Kemendikbud. (2017). Materi Pendukung Literasi Finansial. Jakarta: Tim GLN Kementrian Pendidikan dan Kebudayaan

[23] Wahyuny, Ikka Noor. (2015). Pengembangan Pendidikan Financial Literacy Berbasis Nilai-

[24] nilai Anti Korupsi Sebagai Investasi Sosial: Sebuah Pemikiran. Prosiding Semiar Nasional Pendidikan Ekonomi \& Bisnis Fakultas Keguruan dan Ilmu Pendidikan Universitas Sebelas Maret Surakarta tersedia pada http://snpe.fkip.uns.ac.id

[25] Wijaya, David. (2014). Pendidikan Antikorupsi: untuk Sekolah dan Perguruan Tinggi. Jakarta:

Indeks 